\title{
Enemies and Heroes of the Faith: Women and the Devil in the Poema de Fernán González
}

\section{Los héroes y enemigos de la fe: las mujeres y el diablo en el Poema de Fernán González}

\author{
JENNIFER M. CORRY \\ Berry College \\ jcorry@berry.edu
}

While it is necessary for Castile to unite against a common enemy, the Muslim enemy isn't enough. The poet adds the supernatural enemy, the Devil, as well as court intrigue instigated by a queen, to ensure there is a proper call to arms while at the same time demonstrating that there is one woman worthy to establish a new Christian Spain with the poem's hero and avenge the women who were sacrificed when Spain first fell to the Moors.

KEYwORDs: Devil, women, sorcery, Christ figure, Moors

Mientras es necesario que Castilla se una contra un enemigo común, el enemigo musulmán no es suficiente. El poeta añade el enemigo sobrenatural, el Diablo, tanto como la intriga de la corte provocada por una reina, para asegurar que hay una llamada adecuada a las armas mientras a la vez demuestra que hay una mujer digna de establecer una nueva España cristiana con el héroe del poema y para vengar a las mujeres que fueron sacrificadas cuando España cayó ante los moros.

Palabras Clave: Diablo, mujeres, hechicería, figura de Cristo, moros

FECHA DE RECEPCIÓN: 04/04/2017

FECHA DE ACEPTACIÓN: 01/09/2017

$\mathrm{I}$

$\mathrm{t}$ is well established that the Poema de Fernán González was written largely to illustrate and glorify Castile's place as ruler over Christian Spain as well as to aggrandize the memory of the Count and the fame of the Monastery 
of Arlanza (Duque, “Cómo se exalta a un héroe", 211). Historically, at the time Fernán González was appointed Count of Castile by King Ramiro II of León, Castile formed a section of León that would need to vanquish both León and any advancing Moorish armies in order to establish its superiority. To portray this, the poet closely identifies the hero with Castile so that it seems that he is an embodiment of the land itself (Such and Rabone, "Introduction", 67). "There seems to be little doubt that our poet intends to present the Castilians as a chosen people, condemned to endure a lengthy period of suffering, but eventually brought to freedom from the oppression that they had endured under the Moors (and, by extension, under their Leonese neighbours as well) through the sacrifice of brave warriors led by Fernán González" (Such and Rabone, "Introduction", 82). Castile faces three basic political conflicts in the poem, that against the Moors, León, and Navarre, and establishes an unquestionable hierarchy with Fernán González as Castile’s saintly ruler (Martín, "Conflicto político", 192-201). To establish this hierarchy as well as tie the hero to the land, the poet uses both women and the Devil to accentuate the contrast and allude to the protagonist's saintly qualities so that he becomes a larger-than-life savior figure for Christian Spain.

\section{DeVIL}

The Devil, references to whom appear in abundance throughout the poem, historically could be portrayed in a number of ways. For example, in popular Christian stories, he was often depicted as frightening in order to inspire the audience to avoid sin. In folkloric tales, however, he was often portrayed in a ridiculous fashion in order to allay fears and tensions (Russell, Lucifer, 6263). The Devil of the $P F G$ is of the more frightening type to serve as a worthy counterbalance to Fernán González’s mighty deeds. The Devil and allusions to the Devil appear plentifully in the poem beginning with Visigothic kings falling prey to the Devil's wily ways. ${ }^{1}$ It is clear that the work of the Devil allied with the Moors causes Christian Spain to fall (Bailey, "El diablo como protagonista", 172), which Rodrigo points out when he addresses the court

1 "Fijos de Vautiçanos non devieran nasçer, / que éssos començaron traïçión a fazer; / volvió lo el diablo, metió y su poder; / esto fu’ el escomienço de España perder” (41). 
blaming the Devil for Spain's demise. ${ }^{2}$ The Devil seeks only to hurt Christians ${ }^{3}$ and, because no one is able to defend against him, Spain tumbles into the clutches of the devilish Moors. The poet tightly binds the Devil to the Moors as they ride through Spain conquering all but a few pockets of territory in the north, and committing unspeakable acts, ${ }^{4}$ thus ensuring that the reader understands that this destruction was brought about by God's permission because of the Christians' inability to remain pure in their faith. ${ }^{5}$

Spain spends many years in this punishment meted out by the Devil and the Moors, but all is not lost. Quietly, the stage has been set for the hero Fernán González to appear. ${ }^{6}$ Following folkloric motif and placed among the grandest of heroes such as Moses, Romulus, King Arthur, and Amadis (Avalle-Arce, "El Poema de Fernán González”, 63, 68; Geary, “The 'tres monjes', 24; Keller, "El misterioso origen”, 44), Fernán González at a young age is stolen away from his parents and raised in humble conditions by a carbonero, a charcoal worker ${ }^{7}$ (177), which is significant because of later description of Satan and the Moors as carboniento, ${ }^{8}$ enhancing the unholy alliance between them that the poet wishes to establish. Historically, the Devil's color has been depicted as black, in conformity with Christian tradition and almost worldwide symbolism. His skin is black, or he is a black animal, or his clothing is black, or, to a lesser extent, he is sometimes portrayed as red or green (Russell, Lucifer, 68). While it has been suggested that the charcoal worker serves as a Devil figure (West, Epic, Folk, and Christian Traditions, 39), this figure could

2 "Fue fecha la barata atal com' entendedes, / volvió lo el diablo que tiende tales redes; / trastornó el çimiento, cayeron las paredes: / lo que estonz’ perdiestes cobrar vos lo podedes” (68).

3 "el diablo antiguo en esto s'trabajava / por fer mal a cristianos - nunca en al andava -" (70).

4 “Dezién e afirmavan que los vieran cozer: / cozían e asavan los omnes por' comer;" (93) and "Perdieron muchos d'ellos de miedo los sentidos; / matavan a las madres, en braços a los fijos;" (95).

5 “Diera Dios essas oras grand poder al pecado: / fasta allend' el puerto todo fue astragado" (101).

6 "éste fue de los moros un mortal omiçero; / dizien le por sus lides el bueitre carniçero" (174).

${ }^{7}$ As noted by Diego Catalán, J.P. Keller and Mercedes Vaquero, the oral tradition or lost Cantar likely did not include a reference to the carbonero but rather to a caballero as evidenced by the appearance of the caballero in the Primera crónica general and the Crónica de 1344 (Catalán 565; Keller, “El misterioso origen”, 42; Vaquero, “¿Qué sabemos del Cantar?”, 207). Keller observes that the caballero eliminates the contrast afforded by the carbonero (44).

8 "quand' sale del infierno suzio e carboniento" (388) and "Ayuntan los diablos con sus conjuramentos, / aliegan se con ellos e fazen sus conventos; / dizen de los pasados todos sus falimientos; / todos fazen conçejo, los falso carbonientos" (478).

Medievalia 49, 2017, pp. 63-71 
also be understood as someone who trains Fernán González how to vanquish those who are carbonientos. Like the Cid, who wielded the sword Tizón, meaning charred wood, Fernán González grows up learning to char wood by commanding fire, an element necessary to life, as well as the element the Qu'ran states that God used to make the djinn Iblis or Shaytan. ${ }^{9}$ Charred wood, evoking images of the hearth, home, warmth, and dominance over fire and nature, and in the hands of a common man, salt of the earth, bring powerful imagery to Fernán González's upbringing. The rise from the humble upbringing by the carbonero also evokes the idea of upward social mobility, which was made possible in Spain by the process of the Reconquest. Soldiers and settlers were needed both to fight in battles against Christian enemies as well as to occupy reconquered territory. ${ }^{10}$ The image of the larger-than-life hero rising from humble origins could very well has served as inspiration to young men from all economic classes to fight for Castile. His humble rearing not only teaches him to dominate the most basic of elements necessary to survival but also prepares him to face the most dangerous of foes, foreshadowing his victory over the fiery, devilish Moors.

At the battle of Hacinas, the extraordinary sight of the flying serpent ${ }^{11}$ evokes a myriad of possible symbolic meanings beyond the initial association with the Devil. While serpents have often been associated with evil, they are also associated with healing and with various classical pagan gods such as Aetérnitas, Aion, Athena, Apollo, Asklepiós, and Chnubis (Lurker, A Dictionary of Gods), among others. It is also the biblical Isaiah 27 that depicts a similar flying serpent, "In that day the Lord will punish Leviathan the fleeing serpent, with His fierce and great and mighty sword, Even Leviathan the twisted serpent". Historically the Devil has often been associated with serpents who have also served as symbols of adversity or punishment. Many saints have been depicted defeating snakes as a sign of their virtue (Duque, "Cómo se exalta a un héroe”, 221). The Basque pagan god Sugaar, who was associated with the Devil, was thought to live underground in the form of a snake and traverse the heavens like a fiery sickle (Lurker, A Dictionary of Gods, 332).

9 “[ Allah ] said, What prevented you from prostrating when I commanded you?" [Satan] said, "I am better than him. You created me from fire and created him from clay" (Surah 7:12).

${ }^{10}$ Privileges and concessions were given to those who agreed to repopulate reconquered territory (Such and Rabone, "Introduction”, 14).

11 "Vieron aquella noche una muy fiera cosa: / venía por el aire una sierpe raviosa / dando muy fuertes gritos la fantasma astrosa; / toda venié sangrienta, bermeja commo rosa” (468). 
The fact that the poem's serpent is on fire ${ }^{12}$ associates it to the Islamic Devil, Iblis, and helps to tie the image of the Devil to the Moors as well as assure the reader that the hero can defeat it because he is a master of fire thanks to his upbringing with the carbonero. Notably, the serpent is already wounded, evoking images of a celestial battle between Satan's demonic armies and God's angelic hosts before the similar battle on Earth between good and evil takes place, and at the same time foreshadowing the Christian victory.

Like the Cid's men who are frightened by the lion when the Cid is sleeping, the Count's men are frightened by this serpentine apparition while the Count sleeps and they go to wake him. In fact, the Count does not have the opportunity to fight or even see the snake because it disappears before he arrives ${ }^{13}$ suggesting that it knows the Count is capable of defeating it, further reassuring the Christian medieval audience that a Christian victory is assured.

The Count explains to his men that the Moors dabble in evil magic, ${ }^{14}$ including enchantments and astrology which are closely associated with demons, and again the word carboniento appears in association (478). It is an opportunity for the poet to highlight the benefits and salvation the Church offers in stark contrast to the soot covered, evil Moors. This is more than just two earthly armies clashing in a dispute over land, it is a battle for souls (Bailey, "El diablo como protagonista", 179). The Count calms his men with the explanation that, although the Moorish magicians have the power to transform a demon's appearance into a serpent, it is only an illusion meant to frighten them into running away from the battle. The Count reminds the troops that it is only the belief in Jesus Christ and God ${ }^{15}$ that will bring righteousness in this battle of good and evil, which also has the effect of further associating the

12 “Fazié ella senblante que ferida venía; / semejav' en los gritos que el çielo partía. / Alunbrava las uestes el fuego que vertía; todos ovieron miedo que quemar los venía” (469).

13 "Despertaron al conde que era ya dormido; / ante que él veniesse el culebro fue ido" (471).

14 "Los moros, bien sabedes, se guían por estrellas; / non se guían por Dios, que se guían por ellas. / Otro Crïador nuevo han fecho ellos d'ellas; / diz que por ellas ven muchas de maraviellas. // Ha y otros que saben muchos encantamientos; / fazen muy malos gestos con sus esperamientos / de revolver las nuves e revolver los vientos; / muestra les el diablo estos entendimientos. // Ayuntan los diablos con sus conjuramentos, / aliegan se con ellos e fazen sus conventos; / dizen de los pasados todos sus falimientos; / todos fazen conçejo, los falso carbonientos. / / Algún moro astroso que sabe encantar / fizo aquel diablo en sierpe figurar / por amor que podiesse a vos mal espantar; / con este tal engaño cuidaron nos tornar” (476-479).

15 “ca quitó l'Jesu Cristo el su fuerte poder; / veades que son locos los que l' quieren creer. / Que es de tod' el mundo en Uno el poder, / qu’ Él sólo debemos todos obedesçer; / ca Él es poderoso de dar e de toller: / a tal Señor com’éste debemos nos temer” (480-481).

Medievalia 49, 2017, pp. 63-71 
Count with Christ and his God-ordained place as ruler of the dawning Christian Spain. Clearly the lines are drawn between good and evil. God is on the side of the Christians and the Devil fights with the Moors, "Quien este Señor dexa e en la bestia fía, / tengo que es caído a Dios en muy grand ira: / anda en fallimiento la su alma mesquina; / quantos que ansí andan el diablo los guía” (482). The soldiers accept the host in preparation for their battle against the Devil with the confidence that God is fully on their side, as He must be in order to defeat the demonic forces opposing them. ${ }^{16}$

It is notable that later, the Count is compared to a serpent, "El conde don Fernando, más bravo que serpiente, / avía la grand fuerça con el día caliente;" (518) to plainly illustrate that he is far more powerful than the Beast that has attempted to destroy the rising Christian Spain. While the hero par68 takes of magical activities, largely in the form of prophetic visions, the poet divides the Christian magic that supports Fernán González as the head of Christian Spain's new center, Castile, from his demonic Moorish opponents.

\section{WOMEN}

Although the Christians have triumphed at Hacinas, the Devil has not relinquished his hope of crushing the Count and chooses to work through a woman to attempt to defeat him. Teresa, Queen of León, and sister of the fallen King Sancho of Navarre, is the only one dismayed by the Count's appearance at court. ${ }^{17}$ The Devil works through her as the poet declares, "demostró l' el diablo el engaño aína” (584). While feigning love for the Count, the Queen promises him her niece's hand in marriage while at the same time writing a treacherous letter to King García of Navarre asking him to kill Count Fernando. Because the Devil is working through her, she forms an evil contrast against God's chosen hero thereby identifying who is in the right and who is the traitor. A profound sense of loyalty is a central theme to the poem (Hazbun, "Female Foundations", 28). Although Queen Teresa has remained loyal to her brother and to her land of León and Navarre, the poet makes it clear that Castile is now God's elected center of the new Christian Spain and

16 "Todos, grandes e chicos, su oraçión fizieron; / del mal que avién fecho todos se repintieron; / la ostia consagrada todos la resçebieron, / todos de coraçón a Dios merçed pedieron" (485).

17 "A chicos e a grandes de toda la çibdat / la venida del conde plaçié de voluntad; / a la reïna sola pesava por verdat, / que avía con él muy grand enemistad” (574). 
that Count Fernán González is the chosen one to establish it. Therefore, any loyalties that are given precedence over the Count will be considered treasonous and even demonic to underscore the seriousness of the message.

To enhance this idea, the poet alludes to a comparison between the Count and Christ in various instances including when King García imprisons the Count, a voice, like the cry of a peacock, symbolizing resurrection and the immortal sanctity, and omnipotence of the Church, rings out and splits the al$\operatorname{ter}^{18}$ followed by Fernando passing into a crisis of faith on the eve of Christian Spain's resurrection as he asks God, "Señor del mundo, ¿por qué me has fallido?" (601) a clear allusion to Christ's despairing question (Matthew 27:46) on the eve of his crucifixion and subsequent resurrection. The various celestial visions the hero has further contribute to establishing a legitimate hierarchy (Martín, "Conflicto político", 195). He is indeed a leader chosen by God.

Later, the Devil and Teresa's secret plot is exposed when the Count of Lombardy explains to Sancha, the hero's future wife, that the fate of all Castile is in her hands. ${ }^{19}$ She holds all the power in her hands and, like the Virgin, she is expected to intercede on Castile's behalf. As has been discussed in a number of scholarly works, Sancha proves herself a loyal and worthy companion to the Count. She not only rescues him from prison, but also carries him $^{20}$ in a show of strength that has been likened to the Amazons (Irizarry, "Echoes of the Amazon Myth", 59). She is a woman to be reckoned with and unafraid of the risks such a venture requires. ${ }^{21}$

In contrast, the evil archpriest, representing the remnant corrupt Christian Spain that was overrun by the Moors, finds the Count and Sancha during their escape and demonstrates a complete lack of true Christian values as evidenced by his demand that he have his way with the lady. ${ }^{22}$ Sancha overcomes the archpriest's advances and declares, "Don traïdor, de ti seré vengada" (656). She has her vengeance not only for his presumptuous advances upon

\footnotetext{
18 “oyeron una voz commo voz de pavón; / partió se el altar de somo a fondón” (599).

19 "Dueña sin piedad e sin buen conosçer, / de fazer bien o mal tú tienes el poder: / si al conde non quieres de muerte estorçer / aver se ha Castiella por tu culpa perder" (624).

20 "el conde don Fernando no podía andar; / ovo l' ella un poco a cuestas a llevar" (644).

${ }^{21}$ Taran Johnston, who establishes Fernán González’s quest as a pilgrimage, states, "Pilgrimage was seen as a risky venture for a woman's safety and an especially suspect endeavor in terms of her virtue and honor; hence the medieval adage 'salir romera y volver ramera.' By suffering a potentially compromised reputation, Sancha really is risking everything for her imprisoned husband, whose honor rests in part on hers" (398).

22 "diz, 'Conde, si tú quieres que sea poridat, / dexa me con la dueña conplir mi voluntad” (650).
} 
her own person, but also for the 100 virgins that the old, defeated Christians of Rodrigo's fallen Spain were forced to give to al-Mansur. ${ }^{23}$ Sancha has not only proven herself a valuable companion to the Count, but also rises to a status worthy to become a new mother and redeemer to the land on the dawn of a new, pure, Christian Spain with Castile at the head. It is she who has killed the remnant of the old, corrupt Christian Spain and promises the creation of a pure lineage with the Count.

The Devil fades from the poem once Fernán González and Sancha's future together is assured. Castile's rise and preeminence is certain and a divine reason to continue fighting the devilish Moors has been established. The Devil, it turns out, can be defeated by divinely chosen Christians who possess God-given, extraordinary abilities.

\section{WORKS Cited}

Avalle-Arce, Juan Bautista, “El Poema de Fernán González: Clerecía y juglaría”, Philological Quarterly, 51, 1, 1972, 60-73.

Bailey, Matrhew, "El diablo como protagonista en el Poema de Fernán González: un concepto clerical de la historia”, Olifant, 20, 1-4, 1995, 171-89.

Catalán, Diego, La épica española: nueva documentación y nueva evaluación, Madrid: Fundación Ramón Menéndez Pidal y Seminario Menéndez Pidal Universidad Complutense de Madrid, 2001.

Duque, Adriano, "Cómo se exalta a un héroe: la oración de los castellanos (105113) en el Poema de Fernán González y su relación con la Puerta del Juicio Final de la catedral de León”, La Corónica: A Journal of Medieval Hispanic Languages, Literatures, and Cultures, 35, 2, 2007, 209-226. http://muse.jhu.edu/article/429795/pdf ec

Geary, John S., “The 'tres monjes' of the Poema de Fernán González: Myth and History", La Corónica, 19, 2, 1990-1991, 24-42.

Hazbun, Geraldine, "Female Foundations in the Libro de Alexandre and Poema de Fernán González”, in Xon de Ros and Geraldine Hazbun (eds.), A Companion to Spanish Women's Studies, Woodbridge: Tamesis, 2011, 25-40.

IrIZARry, Estelle, "Echoes of the Amazon Myth in Medieval Spanish Literature", in Beth Miller (ed.), Women in Hispanic Literature: Icons and Fallen Idols, Berkeley: University of California Press, 1983, 53-66.

23 “Avían en tod' esto de a Almozor dar / çient doncellas fermosas que fuesen por casar; / avién las por Castiella cada un’ a buscar; / avién lo de cumplir pero con grand pesar” (104). 
Johnston, Taran, “The Empire Strikes Back: Hagiographic Imagery in the Poema de Fernán González”, La Corónica: A Journal of Medieval Hispanic Languages, Literatures, and Cultures, 36, 2, 2008, 393-413.

Keller, J. P., “El misterioso origen de Fernán González”, Nueva Revista de Filología Hispánica, 10, 1, 1956, 41-44. <http://www.jstor.org/stable/ 40296972?se$\mathrm{q}=1$ \#page_scan_tab_contents $>$.

Lurker, MANFred, A Dictionary of Gods and Goddesses, Devils and Demons, London and New York: Routledge, 1984.

Martín, Óscar, “Conflicto político en el Poema de Fernán González", Romance Quarterly, 61, 3, 2014, 192-201.

Russell, Jeffrey Burton, Lucifer: The Devil in the Middle Ages, Ithaca and London: Cornell UP, 1984.

Such, Peter and Richard Rabone, editors. Introduction. The Poem of Fernán González, Oxford: Oxbow Books, 2015, 1-104.

Vaquero, Mercedes, “¿Qué sabemos del Cantar de Fernán González?”, Romance Quarterly, 61, 3, 2014, 202-214.

West, Beverly, Epic, Folk, and Christian Traditions in the Poema de Fernán González, Madrid: Jose Porrúa Turanzas, 1983. 
